\title{
A német stratégiai vízió átalakulása a 2010-es években
}

\begin{abstract}
A tanulmány az elmúlt évtizedben elfogadott német stratégiai dokumentumok és szakpolitikai iránymutatások primer elemzésén keresztül vizsgálja a német stratégiai gondolkodás elmozdulását az aktívabb nemzetközi szerepvállalás irányába, rámutatva a 2020-as évekre kialakult stratégiai jövőkép jellemzőire is. Az elemzés elsőként az egyes dokumentumok stratégiai környezetről kialakított koncepcióját vizsgálja, azaz, hogy milyen földrajzi fókuszú és milyen jellegü fenyegetésekkel számolnak, milyen lehetőségeket látnak az érdekérvényesitésre, milyen külpolitikai eszközöket helyeznek elötérbe, milyen keretben képzelik el a honvédelmet és a nemzetközi müveleteket, illetve hogy hogyan viszonyulnak a katonai erő alkalmazásához. A vizsgált tényezők második csoportja a fegyveres erőkhöz kapcsolódóan azt vizsgálja, hogyan változott a német védelmi költségvetés 2008 óta, illetve hogy hogyan néz ki az egyes költségvetési területek finanszírozása, mi a stratégiai jövőkép a fegyveres erők használatához kapcsolódóan, illetve mik a fegyveres erök feladatkörei. Arra is kitér az értékelés, hogy a nemzetközi együttmüködés fokozása megjelenik-e a képességfejlesztés területén. Mindebböl átfogó képek alkotnak a szerzők a német stratégiai vízió változásáról kül-, biztonság- és védelempolitikai megközelitésben.
\end{abstract}

Kulcsszavak: Németország, stratégia, Bundeswehr, védelempolitika, Európa

\section{The Transformation of Germany's Strategic Vision in the 2010s}

The study examines the transformation of German strategic thinking towards assuming greater international responsibilities through the analysis of strategic documents and policy papers adopted in the past decade. It also identifies the characteristics of Germany's strategic vision for the 2020s. First, the analysis examines the conceptual picture of the documents regarding Germany's strategic environment, namely the geographical focus and character of the perceived threats, the identified opportunities for pursuing German interests, the prioritised foreign policy tools, the primary frameworks for homeland defence and international operations, as well as Germany's readiness to use military force. The second batch of factors examined is related to the armed forces, analysing the changes in the German defence expenditure since 2008, the financing of respective budgetary fields within defence spending, as well as the future strategic view for the use of the armed forces and its future

\footnotetext{
Altdorfer Domonkos a Nemzeti Közszolgálati Egyetem végzett hallgatója. E-mail: altdorfer.domonkos@gmail.com

2 Csiki Varga Tamás PhD a Nemzeti Közszolgálati Egyetem Eötvös József Kutatóközpont Stratégiai Védelmi Kutatóintézet tudományos munkatársa. E-mail: csiki.tamas@uni-nke.hu
} 
tasks. The analysis also examines whether intensifying international cooperation was a determining factor of capability development. Based on all these factors, the authors offer a comprehensive picture of the changes of Germany's strategic vision from a foreign, security and defence policy point of view.

Keywords: Germany, strategy, Bundeswehr, defence policy, Europe

\section{Bevezetés}

Az elmúlt 30 évben Európa, és ezen belül Németország biztonsági helyzete legalább háromszor ment át jelentős átalakuláson. A hidegháborút követő enyhülés teljesen új biztonsági architektúrát hozott létre a föderális államszerveződések - a Szovjetunió és Csehszlovákia békés, Jugoszlávia háborús - felbomlásával, majd ezt követően az euroatlanti integráció fokozatos kiterjesztésével Közép-Európa legtöbb állama számára. Az újonnan kialakult nagyfokú belső stabilitást és békét az ezredfordulót követően számottevő katonai fenyegetés nem érte, elsősorban nem katonai kihívásokkal szembesültek a térség államai (például a terrorizmussal), aminek következtében Európa - és a NATO - figyelme a külső válságkezelés felé fordult. A kevéssé sikeres afganisztáni, iraki és líbiai beavatkozások után Oroszország agresszív fellépése Ukrajnával szemben 2014-ben, a Krím elcsatolása jelentette a harmadik hangsúlyváltást, aminek nyomán az európai államok ismét (kollektív) védelmi képességeik megerősítésére kezdtek koncentrálni. Bár a 2010-es években a válságok sora folytatódott, Európa eddig a tradicionális nagyhatalmak vezetésével is kevés valós szándékot és képességet tudott felmutatni ezek kezelésére, annak ellenére, hogy a védelmi együttmüködési kezdeményezések az Európai Unió keretében és azon kívül is sokasodtak. Ezzel párhuzamosan pedig a nemzetközi környezet kedvezőtlen változásai - elsősorban a brexit és Donald Trump elnöksége, valamint Európa keleti és déli szomszédságában egy állandó válságövezet kialakulása - egyre inkább arra kényszeríti a kontinentális államokat, hogy saját kezükbe vegyék biztonságuk garantálását, szomszédságuk stabilizálását.

Az 1990-es újraegyesítés óta Németország egyértelműen a kontinens egyik, ha nem „a” legmeghatározóbb államává vált mind politikai, mind gazdasági értelemben. Ennek következtében már a német biztonságpolitika sem értelmezhető pusztán nemzeti keretek között. Növekvő nemzetközi súlya és európai befolyása, valamint a biztonsági környezet fokozatos romlása a korábban jellemzően visszafogott kül- és biztonságpolitikát folytató Németországot a történelmi hátterü önkorlátozás újraértékelésére, aktívabb nemzetközi szerepvállalásra sarkallta. Ebben a folyamatban nem elhanyagolható szempontot jelentettek a regionális nagyhatalommal szemben támasztott növekvő elvárások mind nyugat-európai, mind transzatlanti szövetségesei részéröl. 
Az elmúlt években több hazai kutató is vizsgálta a német kül- és biztonságpolitika, ${ }^{3}$ védelempolitika, ${ }^{4}$ stratégiai gondolkodás, ${ }^{5}$ valamint nemzetközi müveleti szerepvállalás ${ }^{6}$ jellemzőit és változását. Azonban ezekben az esetekben is azonosíthatunk tematikus és módszertani hiányterületeket, elsősorban a stratégiai gondolkodás terén. Ezért jelen tanulmány erre a területre fókuszálva hiánypótló céllal az elmúlt évtizedben elfogadott német stratégiai dokumentumok és szakpolitikai iránymutatások primer elemzésén keresztül vizsgálja a stratégiai gondolkodás elmozdulását az aktívabb nemzetközi szerepvállalás irányában, rámutatva a 2020-as évekre kialakult stratégiai jövőkép jellemzőire is.

Először azt tekintjük át, hogy Németország stratégiai környezete hogyan változott meg a 2010-es években. Ezt követően pedig megvizsgáljuk, hogy ezek a változások miként érhetők tetten a vizsgált időszakban megjelent biztonság- és védelempolitikai dokumentumokban. A dokumentumelemzés a Bundeswehr Társadalomtudományi Intézetének (SOWI)

Hettyey András: Ki az úr a házban? - A német külpolitikai döntéshozatal struktúrája. Európai Tükör, 20. (2017), 1. 63-77.; András Hettyey: A Multilateralized Civilian Power Approach: The German Foreign Policy and Central Eastern Europe. Európai Tükör, 20. (2018), különszám, 71-85.; Speck Gyula: „Germany first” - Az AfD kül- és biztonságpolitikai programja. [online], 2020. 03. 09. SVKI Elemzések, 2020/6. Forrás: svkk.uni-nke.hu [2021. 03. 22.]; Speck Gyula: A ,zöld” külpolitika - A Szövetség '90/Zöldek kül- és biztonságpolitikai programja. [online], 2020. 04. 09. SVKI Elemzések, (2020), 7. Forrás: svkk.uni-nke.hu [2021. 03. 22.], Molnár Tamás Levente: Németország EU-n kívüli kapcsolatai (1.) Oroszország a szankciós politika tükrében. [online], 2017. KKI Elemzések, (E-2017), 41. Forrás: kki.hu [2021. 03. 22.]; Molnár Tamás Levente: Németország EU-n kívüli külkapcsolatai (2.) - Donald Trump és a felforgatott transzatlanti kapcsolat. [online], 2018. KKI Elemzések, (E-2018), 5. Forrás: kki.hu [2021. 03. 22.]; Molnár Tamás Levente: Németország EU-n kívüli kapcsolatai (3.) Fokozódó óvatosság Kínával szemben. [online], 2018. KKI Elemzések, (E-2018), 35. Forrás: kki.hu [2021. 03. 22.]; Speck Gyula: Németország fejlesztéspolitikája, mint a biztonságpolitika eszköze. [online], 2019. 12. 17. SVKI Elemzések, (2019), 26. Forrás: svkk.uni-nke.hu [2021. 03. 22.]; Molnár Tamás Levente: Rendszerszintű rivális vagy kulcsfontosságú partner? (1) Németország Kína-politikája. [online], 2020. KKI Elemzések, (E-2020), 58. Forrás: kki.hu [2021. 03. 22.]

4 Csiki Tamás: A német védelempolitika régi-új alapjai és új felépítménye. Nemzet és Biztonság, 5. (2012), 3. 49-70.; Csiki Tamás: Miért marad továbbra is visszafogott a német védelempolitika? Nemzet és Biztonság, 7. (2014), 5. 97-110.; Csiki Varga Tamás: Vezetőváltás a német védelmi tárca élén. [online], 2019. 08. 12.; SVKI Nézőpontok, (2019), 3. Forrás: svkk.uni-nke.hu [2021. 03. 22.]; Etl Alex - Csiki Varga Tamás: A Bundeswehr finanszírozása és készenléte. [online], 2019. 09. 19. SVKI Elemzések, (2019), 19. Forrás: svkk.uni-nke.hu [2021. 03. 22.], Csiki Varga Tamás - Etl Alex: A Németországban állomásozó amerikai katonai jelenlét csökkentéséröl. [online], 2020. 06. 22. SVKI Elemzések, (2020), 19. Forrás: svkk.uni-nke.hu [2021. 03. 22.]

5 Kiss J. László: Folytonosság a változásban - külpolitikai stratégia és nemzeti identitás a német fejlődésben. In Kiss J. László (szerk.): Nemzeti identitás és külpolitika az euroatlanti térségben. Budapest, Teleki László Alapítvány, 2005. 51-159.; Csiki Tamás: Németország - Európa vezető hatalma, vagy kiszámíthatatlan szövetséges? Nemzet és Biztonság, 6. (2013), 5-6. 63-79.; Csiki Varga Tamás - Etl Alex: A „müncheni konszenzus” és Németország stratégiai jövőképe. [online], 2019. 09. 19. SVKI Elemzések, (2019), 19. Forrás: svkk.uni-nke.hu [2021. 03. 22.]

6 Hettyey András: A szükséges minimum? Németország szerepvállalása Maliban. [online], 2013. MKI Elemzések, (2013), 5. Forrás: grotius.hu [2021. 03. 22.]; Hettyey András: A vonakodó szövetséges? - Németország külföldi katonai bevetései a viták és a számok tükrében. Külügyi Szemle, 13. (2014), 1. 69-87.; Hettyey András: Különutas kezdeményezések: fordulat a német külpolitikában? Nemzet és biztonság, 8. (2015), 1. 46-64.; Hettyey András: Németország Közel-Kelet politikája érdekek és értékek útvesztőjében. Hadtudományi Szemle, 10. (2016), 4. 169-197.; Csiki Varga Tamás: Ambíció és kockázat: a német külpolitika lehetőségei is korlátjai Líbia kapcsán. [online], 2020. 01. 25. SVKI Nézőpontok, (2020), 1. Forrás: svkk.uni-nke.hu [2021. 03. 22.]; Ablaka Gergely - Csiki Varga Tamás - Csizmazia Gábor et alii: Irak stratégiai érdekek ütközőpontjában. [online], 2020. 07. 31. SVK Elemzések, (2020), 21. 16-18. Forrás: svkk.uni-nke.hu [2021. 03. 22.] 
módszertanának ${ }^{7}$ egyes elemein alapul, amelyet már több hazai ${ }^{8}$ kutatásban is alkalmaztak, és a stratégiai kultúra elemzéséhez használatos. A stratégiai kultúra magában foglal minden olyan közös meggyőződést, normát vagy eszmét, amely meghatározza a közösség elvárásait a biztonság- és védelempolitikával kapcsolatban. A stratégiai kultúrába tehát beletartozik mind a politikai elitre, mind a társadalomra vonatkozó attitüd, a SOWI kutatása azonban elsősorban a politikai elitre koncentrált. Az általuk használt keretrendszer négy elemből áll, amelyek fö pontjai a nemzetközi ambíciószint, a végrehajtó hatalom szerepe a döntéshozatalban, a külpolitikai orientáció és a katonai erő alkalmazásához füződő viszony. ${ }^{9}$

Ezek alapján alakítottuk ki azt a keretrendszert, amellyel a stratégiai dokumentumok és iránymutatások elemzését elvégezzük, a fentiek közül a nemzetközi ambíciószinthez, a külpolitikai orientációhoz és a katonai erő alkalmazásához füződő viszony terén. Ezeket finomítjuk és egészítjük ki a védelmi képességek fejlesztéséhez közvetlenül kapcsolódó szempontokkal. Így a vizsgált tényezők első csoportjában az egyes dokumentumok stratégiai környezetről kialakított koncepcióját vizsgáljuk, azaz, hogy milyen földrajzi fókuszú és milyen jellegü fenyegetésekkel számolnak, milyen lehetőségeket látnak az érdekérvényesítésre, milyen külpolitikai eszközöket helyeznek elötérbe, milyen keretben képzelik el a honvédelmet és a nemzetközi müveleteket, illetve hogy hogyan viszonyulnak a katonai erő alkalmazásához. A vizsgált tényezők második csoportja a fegyveres erőkhöz kapcsolódik. Megvizsgáljuk, hogyan változott a védelmi költségvetés 2008 óta, illetve hogy hogyan néz ki az egyes költségvetési területek finanszírozása, mi a stratégiai jövőkép a fegyveres erők használatához kapcsolódóan, a nemzetközi együttműködés fokozása megjelenik-e a képességfejlesztés területén, illetve mik a fegyveres erők feladatkörei. Végül lényegre törő - kulcsszavakat tartalmazó táblázatos - formában összegezzük az eredményeket annak érdekében, hogy könnyen áttekinthetö, komparatív módon szemléltessük a változás folyamatát.

A dokumentumelemzés tárgyát a vizsgált időszak meghatározó, a német kormány, a Védelmi Minisztérium vagy a Bundeswehr vezetése által elfogadott, stratégiai iránymutatást tartalmazó dokumentumok képezik. Ezek a 2011-es Védelempolitikai Irányelvek (Verteidigungspolitische Richtlinien - VPR), ${ }^{10}$ a 2013-as és 2018-as Bundeswehr-koncepció (Konzeption der Bundeswehr - $\mathrm{KdB}{ }^{\prime} 13^{11}$ és $\mathrm{KdB}$ ' $18^{12}$ ), valamint a 2016-os Fehér

Heiko Biehl - Bastian Giegerich - Alexandra Jonas (eds.): Strategic Cultures in Europe. Security and defence policies across the continent. Springer, Potsdam, 2013. 13-16.

8 Csiki Tamás - Tálas Péter: Can we identify a coherent strategic culture in Hungary? In Biehl - Giegerich -Jonas (eds.) (2013) i. m. 165-180.; Csiki Tamás - Tálas Péter: Stratégiától stratégiáig. A 2009-es és a 2012-es magyar katonai stratégia összehasonlító elemzése. Nemzet és Biztonság, 7. (2014), 2. 62-76.; Csiki Tamás: Az új Nemzeti Katonai Stratégia a nemzetközi tapasztalatok tükrében. Nemzet és Biztonság, 7. (2014), 2. 45-61.; Csiki Varga Tamás: A kelet-közép-európai államok védelmi együttműködési törekvései, 2008-2016. Doktori értekezés. Budapest, NKE HDI, 2018; Szabolcs Laura: Európai stratégiai autonómia - A közös védelem alapjai és korlátjai. Nemzet és Biztonság, (2020), 3. (kézirat).

9 Biehl-Giegerich-Jonas (eds.) (2013) i. m. 13.

10 Verteidigungspolitische Richtlinien. [online], 2011. 05. 27. Forrás: bmvg.de [2021. 03. 22.] (A szerzők a továbbiakban VPR rövidítéssel és évszámmal hivatkoznak erre a dokumentumra.)

11 Bundesministerium der Verteidigung: Konzeption der Bundeswehr 2013. [online], 2013. Forrás: bmvg.de [2021. 03. 22.] (A szerzők a továbbiakban KdB rövidítéssel és évszámmal hivatkoznak a forrásra.)

12 Bundesministerium der Verteidigung: Konzeption der Bundeswehr 2018. [online], 2018. Forrás: bmvg.de [2021. 03. 22.] (A szerzők a továbbiakban KdB rövidítéssel és évszámmal hivatkoznak a forrásra.) 
könyv $^{13}$ (Weissbuch - WB). ${ }^{14}$ Ezek hierarchiáját tekintve elmondható, hogy a 2011-es Védelempolitikai Irányelvek és a 2013-as Bundeswehr-koncepció még a 2006-os Fehér könyvre reflektáltak, amely után 2016-ban adták ki az új Fehér könyvet. A 2018-as Bundeswehr-koncepció pedig már ez utóbbihoz kapcsolódik. Kiegészítésképpen, specifikus jellegük miatt azonban csupán jelzésértékkel szerepel az áttekintésben ezeken a dokumentumokon kívül a Bundeswehr szervezeti átalakításáról szóló 2012-es „Drezdai rendelet” (Dresdner Erlass), ${ }^{15}$ a 2014-es "Attraktív Agenda” (Agenda Attraktivität), ${ }^{16}$ a hadsereg vonzó munkaadóvá tételét középpontba helyező miniszteri program, valamint az elemzés végpontját képezö, Annegret Kramp Karrenbauer védelmi miniszter és Eberhard Zorn, a Bundeswehr föszemlélője által 2021 elején a „jövő Bundeswehrjéről” kiadott állásfoglalás (Positionspapier: Gedanken zur Bundeswehr der Zukunft - PP). ${ }^{17}$

\section{A stratégiai környezet változása}

A 2010-es évtizedet nagyjából két időszakra oszthatjuk, ahol a 2014-2016 közötti „átmeneti” időszak jelentette a stratégiai gondolkodás formális tartalmi eltolódását előbb a politikai diskurzus, majd a stratégiai dokumentumok és hosszú távú tervezés tekintetében is. (Természetesen nem veszíthetjük szem elől a német politikai-társadalmi kultúrában még ma is mélyen gyökerező önkorlátozás, stratégiai visszafogottság máig velünk élő elemeit, azaz a tényt, hogy az átmenet fokozatos és nem szükségszerűen egyirányú, nem visszafordíthatatlan. Tanulmányunkban a változások trendjét, hangsúlyait érzékeltetjük, amellett azonban nem tudunk minden kétséget kizáróan érvelni, hogy a folyamat egyes elemei ne változhatnának például a 2021-es szövetségi választás eredményeinek hatására.) Az évtized első éveiben, 2014-ig a gazdasági motivációjú Bundeswehr-reform, a befelé fordulást, önkorlátozást, a katonai erő háttérbe szorítását foglalta keretbe, de az átalakulás elkezdődött. ${ }^{18}$ Minőségi változást a tartalomban a kormányzati konszenzus szintjén azonban a 2014-2015-ös stratégiai sokkok hoztak: a Krím orosz annexiója, a kelet-ukrajnai háború orosz proxyszervezetekkel, az „Iszlám Állam” térnyerése Szíriában és Irakban, a migrációs és menekülthullám Európa irányába, valamint az iszlamista indíttatású terrortámadások. Az évtized második felét a „müncheni konszenzus” kialakulásával jellemezhetjük, amely a nagyobb német nemzetközi szerepvállalás célját rögzítette. ${ }^{19} \mathrm{~A}$ kialakuló „lépéskényszert”a brexit (2015-2020) és Donald Trump elnöksége (2017-2021) tovább erősítették, ugyanis Berlin két olyan hagyományos szövetségesét kezdte elveszíteni (talán csak

13 Fontos jeleznünk, hogy a 2016-os Fehér könyv elfogadásáig az előző, 2006-os dokumentum jelentette azt a keretet, amelyben az összes stratégiai dokumentum megfogalmazta céljait, és amelynek iránymutatásaira hivatkoztak. Így, bár nem esik a vizsgált időszakba és ezért nem is lesz szó róla bővebben, a szükséges vonatkozásokban utalni fogunk rá.

14 Bundesministerium der Verteidigung: Weißbuch 2016 zur Sicherheitspolitik und zur Zukunft der Bundeswehr. [online], 2016. 07. 13. Forrás: bmvg.de [2021. 03. 22.] (Erre a továbbiakban WB rövidítéssel és évszámmal hivatkoznak a szerzők.)

15 Bundesministerium der Verteidigung: Dresdner Erlass. [online], 2012. 03. 21. Forrás: bmvg.de [2021. 03. 22.]

16 Bundesministerium der Verteidigung: Die Agenda Attraktivität. [online], 2014. 06. Forrás: bmvg.de [2021. 03. 22.]

17 Positionspapier: Gedanken zur Bundeswehr der Zukunft. [online], 2021. 02. 09. Forrás: bmvg.de [2021. 03. 22.] (A szerzők a továbbiakban PP rövidítéssel és évszámmal hivatkoznak erre a dokumentumra.)

18 Csiki (2012) i. m. A német védelempolitika régi-új alapjai és új felépítménye.

19 Csiki Varga - Etl (2019) i. m. 
ideiglenesen), amelyek cselekvési potenciálja Európán kívül a korábbi szerepvállalások során kulcsfontosságú eszköz volt.

Így tehát az általunk vizsgált időszak gyakorlati kiindulópontja a 2008/2009-es pénzügyi-gazdasági válság, mivel ez volt annak a védelmi költségvetési megszorításnak a kiváltó oka, ami az évtized első felében a nemzetközi szerepvállalás potenciális katonai eszközének, a Bundeswehrnek az átalakítását, jelentős állomány- és képességcsökkentését is kikényszerítette. ${ }^{20}$ Ezt az időszakot ambivalens külpolitikai magatartás jellemezte a válságkezelés terén (Líbia), Berlin fellépése pedig továbbra is inkább diplomáciai maradt (Ukrajna, Irán). Majd az évtized második felében a 2014-es eseményekre adott reakcióként a még le sem zárult haderö-átalakítás kiigazítására is sor került, miután a német kül- és biztonságpolitikai elit elköteleződött az aktívabb, szükség esetén a katonai erő alkalmazásával is számoló nemzetközi szerepvállalás mellett (Irak). A 2018-ra kialakított hosszú távú haderőfejlesztési célok már alátámasztják a nagyobb nemzetközi ambíciószintet, és a 2020-as évtizedbe lépve egyrészt a kontinentális Európa kollektív védelmét (NATO-keretnemzetként), másrészt a szövetségesekkel és partnerállamokkal folytatott képességfejlesztési, kapacitásbővítési és válságkezelési szerepvállalást szolgálják.

A 2020-as évekbe a „normalizálódás” ellenére a koronavírus-járvány látható és várható gazdasági hatásai miatt jelentős bizonytalansággal léptünk be: miközben Németország és Európa stratégiai környezete tovább fragmentálódott és destabilizálódott (belarusz válság, újabb hegyi-karabahi háború, feszültség a Földközi-tenger keleti medencéjében, a nagyhatalmi erődemonstráció fokozódása Oroszországgal, és a globális versengés erősödése Kínával), a katonai képességfejlesztés és mélyebb együttműködés hátterét adó gazdasági helyzet, erőforrások rendelkezésre állása megkérdőjeleződött. Miközben 2020-ban Németország a Merkel-korszak végére készül, bizonytalan belpolitikai jövőképpel, talán az egyetlen pozitív aktuálpolitikai fejlemény biztonsági környezetében a Biden-elnökség az Egyesült Államokban, amelytől bizonyos mértékű megértő hozzáállást és támogatást remélhet. ${ }^{21}$

A biztonsági kihívások tekintetében is jelentős változásokat tapasztalhattunk az elmúlt évtizedben. Katonai téren Oroszország visszatérése a nagyhatalmi versengésbe, valamint hajlandósága és képessége a hagyományos katonai erők használatára Európán belül az 1990-es évek óta nem tapasztalt közelségbe hozta a katonai konfliktusokat. Emellett a hidegháborús fegyverzetellenőrzési és -korlátozási rezsimek (CFE, INF, Nyitott Égbolt) összeomlottak, a kölcsönös elrettentés a katonai erők előre telepítésével és erődemonstráló hadgyakorlatokkal fokozódik. A nukleáris fenyegetés tekintetében nem csupán Oroszország modernizációs programjaival és a hatékony európai rakétavédelem hiányával kell számolni, de Irán katonai nukleáris programjával is, amelynek korlátozása erősen akadozik. A nem állami szereplők jelentette kihívások ugyancsak terjedtek földrajzi értelemben és bővültek jellegüket illetően: Európát a 2020-as évtizedre az instabil és gyenge államok övezete veszi körül, számos esetben alacsony intenzitású, elhúzódó konfliktusokkal (Ukrajna, Hegyi-

20 Csiki Tamás: A gazdasági válság hatása a Magyarországgal szövetséges államok védelmi reformjaira és stratégiai tervezésére. Nemzet és Biztonság, 7. (2014), 2. 77-100.

${ }^{21}$ Csiki Varga Tamás - Tálas Péter: Erő és diplomácia. Az Egyesült Államok stratégiai érdekei és lehetőségei a Biden-kormányzat időszakában. SVKI Elemzések, (2021), 9. (kézirat). 
Karabah, Irak, Szíria, Líbia, Száhel-övezet, Kelet- és Közép-Afrika), szélsőséges fegyveres csoportokkal, radikális és terrorszervezetekkel. A nem katonai kihívások köre is kibővült: a kibertér sebezhetőségei, a hibrid hadviselés, ezen belül többek között a dezinformáció különböző formái, az olyan transznacionális kihívások, mint a migráció, új válaszok megfogalmazására kényszerítik az európai államokat. Mindezen túlmenően pedig a globális nagyhatalmak, az Egyesült Államok és Kína versengése és a nemzetközi gazdasági folyamatok is sebezhető helyzetbe hozták Európát, benne pedig Németországot. Ezekre a fejleményekre kellett reagálnia a német politikai és katonai elitnek, kül-, biztonság- és védelempolitikai közösségnek, stratégiai gondolkodásnak. A stratégiai dokumentumokban megfogalmazott gyakorlati eredményeket tekintjük át és értékeljük a következő részben.

\section{A német stratégiai dokumentumok elemzése}

A nemzetközi biztonsági környezet változásaira adott kül-, biztonság- és védelempolitikai válaszokról tehát a német stratégiai dokumentumokból kaphatunk átfogó képet. Ennek érdekében a következő rész dokumentumelemzés alapján előbb a biztonsági környezet német percepcióját, majd a kihívásokra adott lehetséges válaszok közül a katonai elemet, azaz a Bundeswehr lehetséges alkalmazásának lehetőségeit mutatja be.

\section{A stratégiai környezetröl alkotott kép}

A 2010-es években született stratégiai dokumentumok értékelése során megközelítésünk a stratégiai környezet fent leírt változásaira adott német válaszokat helyezi a középpontba. A stratégiai környezetről alkotott képnél először a fenyegetések földrajzi fókuszát vizsgáljuk, azaz, hogy mely térségben azonosítanak olyan problémákat és lehetőségeket, amelyek a biztonságpolitikához kapcsolódnak. Mindegyik vizsgált dokumentumról elmondható, hogy globális szemléletű, ezen belül pedig az Európa perifériáján fekvő régiók eseményei a meghatározóak. Szignifikáns különbség, hogy míg a 2011-es VPR és a KdB '13 nem számol közvetlen konvencionális katonai fenyegetéssel, addig Oroszország növekvő aktivitása miatt a 2016-os WB és a KdB '18 ennek megnövekedett lehetőségét hangsúlyozza. Konkrétabban csak a WB és a 2021-es PP nevez meg térségeket és szereplöket, amelyek szerepe a közeljövőben egy-egy lehetséges probléma vagy konfliktus kapcsán fontos lehet. A WB Kína és India, valamint egyes afrikai és dél-amerikai feltörekvő államok megerősödése kapcsán a jelenlegi nemzetközi erőviszonyok eltolódásából fakadó konfliktusok veszélyére hívja fel a figyelmet. ${ }^{22}$ Oroszországról elmondja, hogy veszélyezteti az európai békerendet, bizonytalanságot okoz ukrajnai aktivitásával, hadserege modernizációjával és hibrid eszközök alkalmazásával. ${ }^{23}$ Emellett Észak-Afrikát, a Száhel-övezetet, a Horn-fokot, a Közel-/ Közép-Kelet térségét és Közép-Ázsiát nevezi problémásnak a terrorszervezetek jelenléte, ${ }^{24}$ vagy a különböző etnikai, politikai, vallási vagy felekezeti konfliktusokból adódó össze-

\footnotetext{
WB (2016) i. m. 30.

WB (2016) i. m. 31 .

WB (2016) i. m. 34.
} 
tüzések, illetve polgárháborúk kialakulásának lehetősége miatt. ${ }^{25} \mathrm{Az}$ afrikai és ázsiai népességnövekedést szintén külön megemlíti a migrációs nyomás kapcsán. ${ }^{26}$ Érdemes jelezni, hogy a vizsgált dokumentumokban a védelempolitika dimenziói között nemcsak a hagyományos hadszínterekkel (szárazföld, légtér, tengerek) találkozunk, hanem külön kezelik a kiber- és információs teret, valamint a világürt is. ${ }^{27}$ A PP 2021-ben már a közeljövőben leginkább problémásnak ítélt konfliktuszónákat és szereplőket említi, és ez esetben is érzékelhető egy új elem és hangsúlyeltolódás: Kínára már úgy hivatkozik, mint feltörekvő nemzetgazdaságra, amely ereje teljében lévő, a nemzetközi szabályokat egyre gyakrabban látványosan áthágó szereplő. Az Indiai- és Csendes-óceán térségével kapcsolatban megállapítják, hogy a nagyhatalmi rivalizálás egyre nagyobb méreteket ölt, ami a Németországgal egy értékközösségbe tartozó szövetséges államokat is egyre jobban aggasztja. Oroszország pedig a Nyugattal szemben definiálja önmagát, egyre égetőbb politikai és katonai veszélyt jelent, mivel folyamatosan fejleszti konvencionális és nukleáris fegyverarzenálját. ${ }^{28}$

A fenyegetések jellegét tekintve mindegyik dokumentum biztonságértelmezése átfogó, aminek lényege, hogy rámutat: a kihívások, fenyegetések politikai, gazdasági, társadalmi, környezeti stb. téren is jelentkeznek, és egy állam biztonságát ma már nem lehet pusztán katonai eszközökkel fenntartani. ${ }^{29}$ Ezenkívül fontos, hogy a külső és belső biztonságot egyre kevésbé lehet elválasztani egymástól. ${ }^{30} \mathrm{~A}$ globalizáció és az információáramlás felgyorsulása nagyban hozzájárult ahhoz, hogy manapság a biztonsági környezet folyamatos változásban van, ami miatt rendkívül nehéz a lehetséges veszélyeket előre jelezni. ${ }^{31}$ Mindegyik iránymutatásban megjelenik a kiber- és információs tér fokozott védelme is, amelyre az állami és nem állami szereplők által folytatott dezinformációs kampányok és a kritikus infrastruktúra sebezhetősége miatt van szükség. ${ }^{32}$ A hibrid konfliktus kifejezést a VPR még nem, utána azonban minden dokumentum használta, a nem állami szereplők befolyásnövekedésére viszont mindegyik figyelmeztet. ${ }^{33} \mathrm{Az}$ éghajlatváltozás következményei, mint például a természeti katasztrófák, valamint az erőforrások, nyersanyagok szükösségéből fakadó problémák is egyre nagyobb hangsúlyt kaptak az évtized során. ${ }^{34}$ Emellett nagy nyomatéka van annak is, hogy Németországnak és Európának, gazdasági hatalom mivoltukból fakadóan, elemi érdeke a nemzetközi kereskedelmi és ellátási útvonalak biztosítása. ${ }^{35}$ Éppen ezért fontos a nemzetközi kalózkodás elleni fellépés is. ${ }^{36}$ Ezek mellett az instabil vagy bukott államokkal, amelyek elősegítik a terrorista- és egyéb bűnszervezetek működését, ${ }^{37}$ az irreguláris migrációval, ${ }^{38}$ valamint járványok és a tömegpusztító fegyverek terjedé-

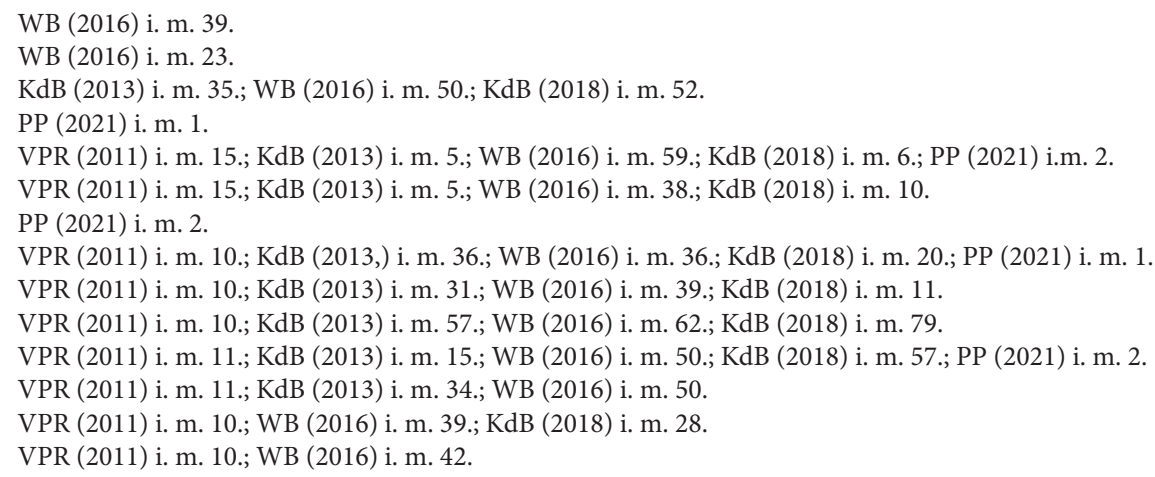


sének veszélyével is számolnak a stratégiai dokumentumok. ${ }^{39} \mathrm{~A}$ korábbi dokumentumok nyilvánvalóan nem számoltak világméretü járvány kitörésének lehetőségével. A PP szerint azonban a koronavírus is a nagyfokú sebezhetőségre mutatott rá. Továbbá kiemelendő, hogy instabilitást okoz a nemzetközi rendszerben a BRICS ${ }^{40}$-államok és egyéb regionális hatalmak (Törökország, Dél-Korea, Mexikó, Irán) térnyerése is. ${ }^{41}$ A fentieken túlmenően a $\mathrm{PP}$ rámutat még, hogy az emberi jogok, a demokrácia és a nemzetközi együttmüködés egyre gyakrabban áll támadás alatt és egyes szereplök ezek szisztematikus gyengítésére törekednek. $^{42}$

Jelentős különbséget találunk az orosz-ukrán konfliktus előtt és után elfogadott stratégiai dokumentumok hagyományos, konvencionális fenyegetésről alkotott képében. A VPR, valamint a KdB '13 még nem számol ennek lehetőségével belátható idő belül, ${ }^{43}$ míg a VB és a KdB ' $18^{44}$ az orosz fellépés alapján már igen. A 2016-os Fehér könyv egyenesen azt írja, hogy „reneszánszát éljük a hagyományos nagyhatalmi politizálásnak”.45

A lehetőségek tekintetében egyértelmüen az európai és az észak-atlanti védelempolitikai integrációk emelhetők ki, ezen belül is az EU Állandó Strukturált Együttmüködése (Permanent Structured Cooperation - PESCO), amely a Lisszaboni szerződés keretében jött létre. ${ }^{46}$ Ugyanitt fontos szerepet kapott a NATO keretnemzet-koncepciója (Framework Nation Concept - FNC), amely egyszerre lehetőség, minthogy Németország képes a feladat ellátására és vezető szerep átvételére, illetve kötelezettség is, hogy a nemzeti képességeit ennek megfelelően fejlessze tovább. ${ }^{47}$ Erre vonatkozóan a KdB '18 úgy fogalmaz, hogy fontos Európa stratégiai autonómiájának megteremtése, javítása. ${ }^{48}$ Pozitív fejleményként a WB még Németország kulturális vonzerejének növekedését említette. ${ }^{49}$ A PP ezzel kapcsolatban azt írja, hogy az új amerikai adminisztráció - teszik hozzá, joggal - továbbra is megköveteli majd a nagyobb hozzájárulást e téren. Berlin az Egyesült Királyságra a brexitet követően is szoros szövetségesként tekint, Franciaországgal és a többi európai állammal pedig továbbra is azon fog munkálkodni, hogy az EU meghatározóbb biztonságpolitikai szereplővé váljon..$^{50}$

Habár védelempolitikai iránymutatásokról van szó, ezekben a dokumentumokban is tükröződik a német kormány azon törekvése, hogy békés úton valósítsa meg külpolitikai céljait, illetve védelempolitikáját. Mindezt multilaterális keretek között hajtja végre, aminek legfontosabb eszközét a nemzetközi szervezetekben való tagság jelenti. ${ }^{51}$ A WB ${ }^{52}$ Németország nagyobb politikai/diplomáciai felelősségvállalásáról ír az ENSZ-en

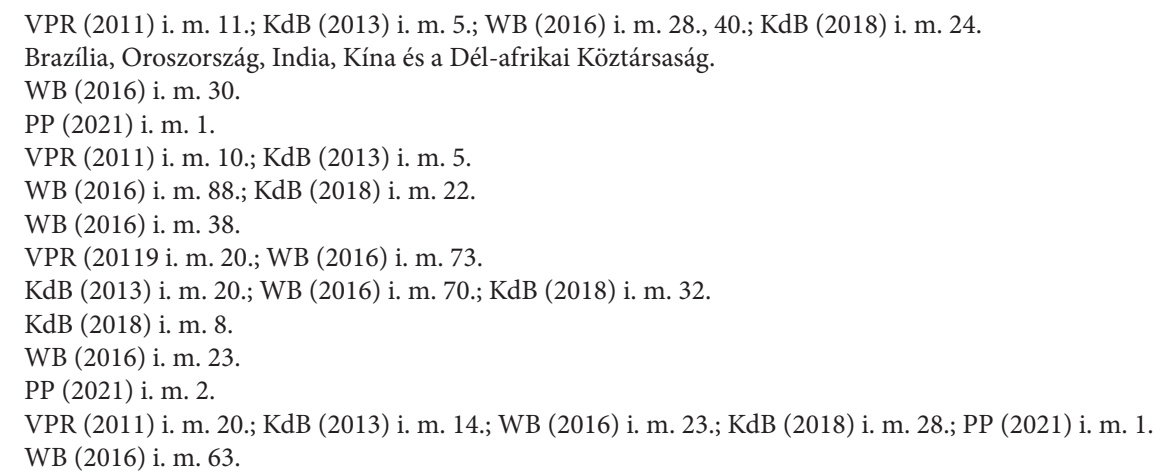


belül - napirenden tartva a német állandó ENSZ BT-tagság kérdését is, ami továbbra is inkább vágyálom, mint reális célkitüzés, hiszen a $\mathrm{BT}$ reformjára az állandó tagok saját hatalmi érdekeik miatt érthető okból nem nyitottak. Ezzel együtt a VPR ${ }^{53}$ hangsúlyozza, hogy Németország akár fegyveres erővel is hajlandó részt venni nemzetközi békefenntartó és békekikényszerítő müveletekben. A KdB ' $13^{54}$ úgy fogalmaz, hogy a biztonság fenntartásához civil és katonai, állami és nem állami intézmények és szervezetek együttmüködése szükséges.

A következő súlypont a honvédelem és a nemzetközi műveletek kereteinek meghatározása. Elmondható, hogy alapvetően mindegyik dokumentum a Bundeswehr képességeire alapozva, NATO- és EU-keretben képzeli el a honvédelmet. Mindegyik iránymutatásban megjelenik, hogy Németország biztonsága csak a NATO kollektív védelmi rendszerén belül szavatolható. ${ }^{55} \mathrm{~A}$ vizsgált dokumentumokban kiemelik a NATO és az Amerikai Egyesült Államok szerepét a nemzetközi válságkezelésben, és a német kormány a transzatlanti szövetség európai pillérének erősítése mellett száll síkra. ${ }^{56}$ Annak érdekében, hogy a kisebb európai szövetségesek haderöfejlesztési és műveleti szerepvállalását magasabb szintre emelhessék, Németország 2013 óta fejleszti a már említett keretnemzet-koncepciót, amelynek egyik vezető nemzete. Emellett fontos az Európai Unió Közös Biztonság- és Védelempolitikai együttmüködése (KBVP) is, amelynek elmélyítése a távlati cél. ${ }^{57}$ Külön ki kell emelni a német szerepvállalást a válságkezelő műveletekben. A NATO kapcsán az Egyesült Államok, míg Európában Franciaország a kiemelt partner (a KBVP kapcsán a weimari hármak összefogását említi a WB) ${ }^{58} \mathrm{~A}$ WB-ban az egyéb két- és többoldalú kapcsolatoknál nevesíti még a tradicionális védelempolitikai együttmüködést Nagy-Britanniával, valamint Németország közvetlen szomszédjaival (Hollandiát és Lengyelországot külön megemlítve), illetve a német-izraeli kapcsolatot. ${ }^{59}$ Emellett hangsúlyos még a legnagyobb ipari és gazdasági hatalmakat tömörítő G7 és G20 formáció, és az olyan „ad hoc" társulások, mint például az E3+3, amely Németország, Franciaország és Nagy-Britannia mellett az Egyesült Államokat, Kínát és Oroszországot foglalja magában. ${ }^{60}$

A vizsgált dokumentumok mindegyike a kül- és biztonságpolitika egyik fő eszközeként tekint a Bundeswehrre, annak feladatköreit pedig részletesen tárgyalják. Első helyen a honvédelmet és az észak-atlanti partnerség jegyében a kollektív szövetségesi védelmet említik, amely NATO-keretek között zajlik. ${ }^{61}$ Ennek kapcsán lényeges különbség mutatkozik a 2014 előtti és utáni időszakból származó dokumentumok között. Mint már említettük, a korábbiak nem számolnak konvencionális territoriális katonai fenyegetéssel, míg a későbbiekben már felmerül ennek veszélye. ${ }^{62}$ De a honvédelem terén a Bundeswehrnek nem csak a hagyományos katonai fenyegetésre kell felkészülnie. A vizsgált dokumentu-

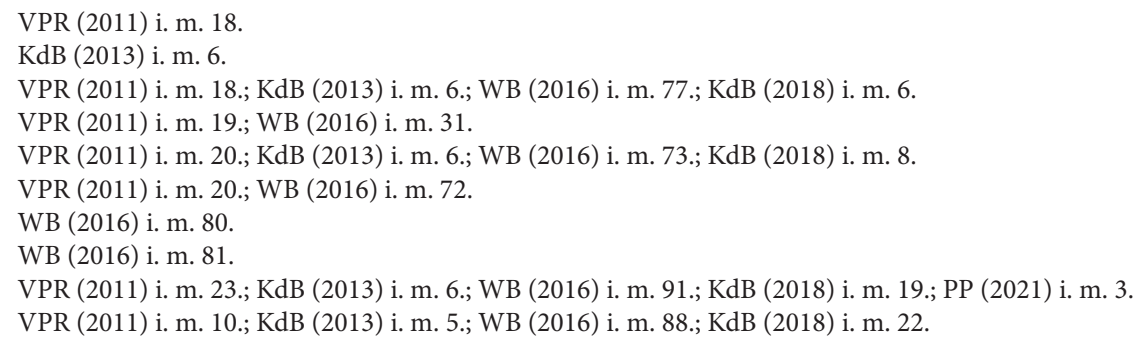


mok egybehangzóan felhívják a figyelmet az aszimmetrikus hadviselés elleni felkészültség fontosságára, különös tekintettel a nem állami szereplökre. ${ }^{63} \mathrm{~A}$ honvédelem mellett tehát a legfontosabb feladat a szövetség határainak védelme, amelybe beletartozik a légtér biztosítása, a rakétavédelem és a tengeri határokon történő együttmüködés. ${ }^{64} \mathrm{~A}$ következő helyen rendszerint a nemzetközi konfliktusmegelőzést és konfliktuskezelést tárgyalják a dokumentumok. ${ }^{65}$ Itt is el kell mondanunk, hogy a VPR és a KdB '13 még ezt tartotta a legvalószínübb feladatnak belátható időn belül. ${ }^{66}$ Ilyen esetekben a hangsúlyt a fenyegetések korai felismerésére és megelőzésére helyezték, illetve már a kialakult válságok esetén a helyreállításra és a stabilizálásra. ${ }^{67}$ Bár nemzetközi színtéren Berlin a diplomáciai eszközöket és a szankciós politikát helyezi előtérbe, ultima ratio jelleggel a harci cselekményekben is hajlandó részt venni NATO- és EU-keretben vagy ENSZ békefenntartó missziókban. Az ENSZ vonatkozásában azonban arról - taktikusan mozgásteret biztosítva a német külpolitikának - nem szólt egyik iránymutatás sem, hogy kötik-e konkrét ENSZ BT-felhatalmazáshoz a nemzetközi katonai fellépést, csupán a nemzetközi jogi legitimitást említik. ${ }^{6}$ Van, ahol részletesebben, van, ahol kevésbé részletesen, de a nemzetközi részvétel jogi szabályozása szintén megjelenik, ahol a nemzetközi jog elsődlegessége hangsúlyos. E tekintetben az ENSZ Alapokmány ${ }^{69}$ és a német parlament felhatalmazása a meghatározók. ${ }^{70}$ A VPR és a KdB '13 az egyidőben külföldi missziókban bevethető haderő létszámát - azaz a nemzetközi ambíciószintet - 10 ezer fóben maximalizálta, de a WB, a KdB '18 és a PP már nem határozott meg konkrét létszámkeretet. ${ }^{71}$

\section{A Bundeswehr szerepe}

A védelmi költségvetés változását szemügyre véve markánsan látszik, ${ }^{72}$ de a 2018 -as KdB külön is kiemeli, hogy az újraegyesítéstől kezdve a védelmi költségvetés aránya a nemzeti össztermék (GDP) arányában folyamatosan csökkent - és ez a trend csak 2014-ben fordult meg. ${ }^{73}$ A Bundeswehr átfogó reformja is a 2008-as világgazdasági válság miatt szükségessé vált pénzügyi megszorítások alapján indult el, és többek között olyan drasztikus változtatásokat eredményezett, mint például a haderő létszámának jelentős csökkentése vagy a kötelező sorkatonai szolgálat 2011 -es felfüggesztése. ${ }^{74}$

A személyi állomány változásánál a leglényegesebb elemnek tehát a kötelező sorkatonai szolgálat felfüggesztése és az állomány létszámának csökkentése tekinthető. Hiába határozták meg a haderő létszámát maximum 185 ezer főben, a kötelező sorkatonai szolgálat

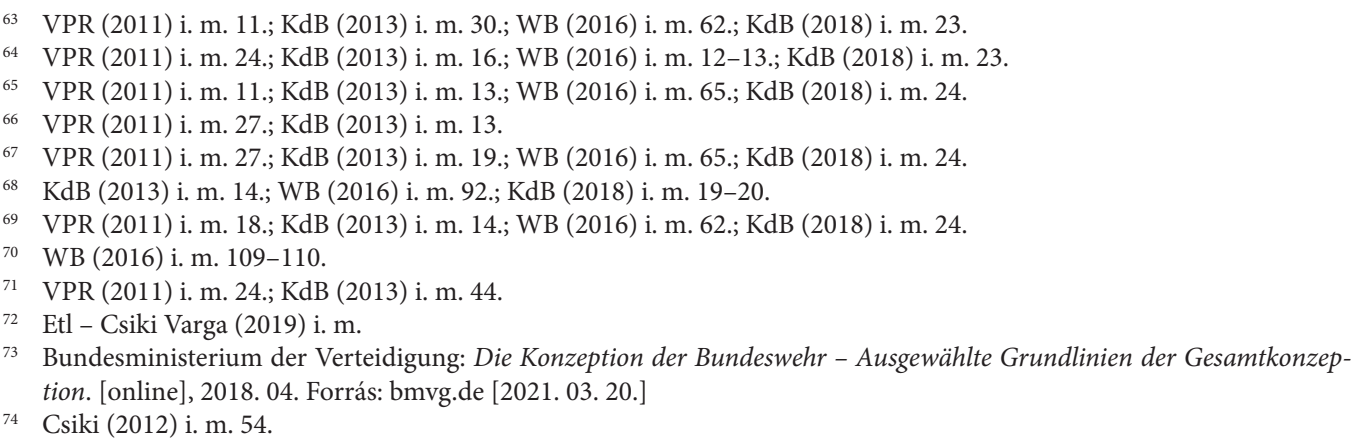


szüneteltetéséből fakadóan a Bundeswehrnek komoly toborzási problémákkal kellett szembenéznie, mivel a katonai szolgálat nem volt elég vonzó a fiataloknak. Már a VPR is azonosította az ebből fakadó nehézségeket. Egyrészt a haditechnikai eszközpark fejlesztésében látja a személyi problémák megoldásának kulcsát (modernebb eszközökkel eredményesebben lehet műveleteket végrehajtani, a technológiai innováció vonzó lehet), másrészt vonzóbb munkaadóvá tenné a Bundeswehrt, növelné a nők arányát, és a szolgálati idő lejártával megkönnyítené az átjárást a civil szférába. ${ }^{75} \mathrm{~A} \mathrm{KdB}$ '13 ugyanerről a problémáról ír, és a vonzó munkaadóvá válást szintén a technológiai fejlesztésben látja. ${ }^{76}$ Ezért az „Attraktív Agendát” 2014-ben kifejezetten ennek a problémának a kezelésére alakították ki, és a miniszteri iránymutatás azt vázolta, hogyan válhat a Bundeswehr a képzett, fiatal munkaerő számára is vonzóvá. A hangsúlyt itt is a munkakörülmények javítására helyezték, valamint egy új életpályamodell, a család, magánélet és munka jobb összehangolhatósága és az esélyegyenlőség biztosítása a fontosabb sarokkövek. ${ }^{77} \mathrm{~A}$ később született dokumentumok mind hivatkozási alapként tekintenek erre a miniszteri programra.

A reformfolyamat, amely tehát csökkentette az állomány méretét, szervezeti szempontból is érintette a Bundeswehrt. A Védelmi Minisztérium 2012-ben hozta nyilvánosságra a Dresdner Erlasst, ${ }^{78}$ amely a föbb szervezeti átalakításokat vázolta a hadsereg felső vezetésében, meghatározta az új alá-fölérendeltségi viszonyokat. Lényeges változások érintették a föszemlélő pozícióját, aki bekerült a minisztérium vezetői struktúrájába. A Bundeswehr legmagasabb rangú katonai méltósága az államtitkárok alatt helyezkedik el. ${ }^{79} \mathrm{~A}$ haderőnemek szemlélői viszont kikerültek a minisztériumi struktúrán kívülre, ezzel nagyobb önállóságot élveznek ${ }^{80} \mathrm{~A}$ többi dokumentum csak általánosságokat fogalmazott meg a szervezet felépítésével kapcsolatban.

Ha azt vizsgáljuk, e dokumentumok milyen stratégiai jövőképet vázolnak a fegyveres erök alkalmazási körével kapcsolatban, megint meg kell említeni a konvencionális területi fenyegetésről alkotott kép változását a krími válság és a kelet-ukrajnai konfliktus tükrében. A korábbi felfogással ellentétben a WB már úgy fogalmaz, hogy „a klasszikus nagyhatalmi politizálás reneszánszát éljük". ${ }^{81}$ Azt azonban mindegyik iránymutatás hasonlóképpen látja, hogy a külső és belső védelem közötti határok elmosódtak. ${ }^{82}$ Ma már a Bundeswehrnek sokkal szélesebb feladatkört kell ellátnia, tevékenysége magában foglalja nemcsak a katonai, de a civil válságkezelést is. ${ }^{83}$

A vizsgált stratégiai dokumentumokban újra és újra előkerül a nemzetközi együttmüködés fokozása. Legyen szó a NATO európai pillérének erősítésérőll, ${ }^{84}$ vagy az uniós biztonság- és védelempolitikai együttmüködés kérdéséről, a német kormány hozzáállása egyértelműen pozitív, sőt a WB-ban úgy fogalmaznak, hogy Németország hosszú távú célja

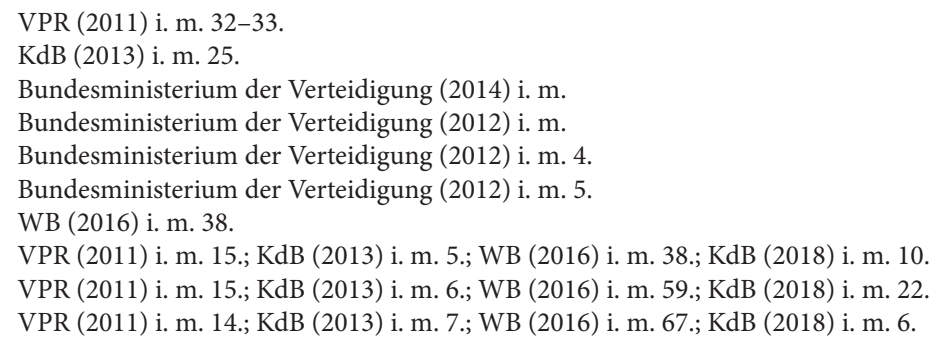


az Európai Védelmi Unió megteremtése. ${ }^{85}$ Németország vetette fel először a keretnemzetkoncepciót is, amelynek lényege, hogy azok az államok, amelyek rendelkeznek a kellő anyagi és emberi erőforrással, hogy haderejüket a (közel) teljes képességspektrumon fenntartsák, integrálhatnák a kisebb államok egy-egy területre specializálódott egységeit, így komplex szövetségesi haderőt képezve. A vizsgált stratégiai dokumentumok ezért szükségesnek tartják a Bundeswehr összhaderőnemi fejlesztését, hogy Németország meg tudjon felelni a keretnemzeti szerep elvárásainak. ${ }^{86} \mathrm{~A} \mathrm{KdB}$ '13 a képességek koordinált fejlesztésének szükségességét hangsúlyozza a hatékonyabb müködés érdekében. ${ }^{87}$

A korábbiakban már esett szó a Bundeswehr föbb feladatköreiröl. Ezeket nagyjából azonos prioritási sorrendben határozták meg a dokumentumokban, azonban két jelentős különbséget így is találunk. Elsőként mindig a hon- és a szövetségesi kollektív védelem szerepel. Ezt a feladatot a két korábbi dokumentumban NATO-keretek között tervezték megvalósítani, míg a részvételt az EU KBVP fegyveres műveleteiben a nemzetközi konfliktuskezelés után a harmadik helyen említik. A 2016-os Fehér könyvben és az azon alapuló KdB '18-ban a NATO mellé került az uniós kölcsönös segítségnyújtáson alapuló önvédelmi mechanizmus (a Lisszaboni szerződés úgynevezett kölcsönös védelmi záradéka) ${ }^{88}$ Ez egyértelmű előrelépésként értelmezhető az európai védelmi együttműködés szempontjából. A nemzetközi válságkezelés mindegyik dokumentumban a második helyen szerepel, ami a különböző multilaterális szervezetek müveleteiben való részvételt jelenti. ${ }^{89}$ A 2014 elötti dokumentumok ennek a feladatnak tulajdonították a legnagyobb jelentőséget, lévén, akkor még nem számoltak klasszikus területi fenyegetéssel belátható időn belül..$^{90}$ Mint már említettük, a dokumentumok alapján Németország akár harci cselekményben is hajlandó részt venni, de a WB emellett már külön kiemeli a civil elemet is a nemzetközi válságkezelés kapcsán. ${ }^{91}$ Ezután jön a válsághelyzetek kezelése az ország területén belül, ami természeti katasztrófák vagy terrortámadás sújtotta területeken való beavatkozást, evakuálást jelent a gyakorlatban. ${ }^{92} \mathrm{~A}$ WB és a KdB '18 idesorolja a nemzetközi túszszabadítást is, amelyet a VPR és a KdB '13 külön kezel. ${ }^{93}$ Következőként rendszerint a nemzetközi biztonság- és védelempolitikai együttmüködést és a nemzetközi humanitárius segítségnyújtást említik. ${ }^{94} \mathrm{~A}$ WB, a KdB '18 és a PP már külön azonosítja a kibervédelmet is a Bundeswehr feladatainál. ${ }^{95}$

85 VPR (2011) i. m. 20.; KdB (2013) i. m. 13.; WB (2016) i. m. 71-72.; KdB (2018) i. m. 8.; PP (2021) i. m. 3.

86 VPR (2011) i. m. 24.; KdB (2013) i. m. 21.; WB (2016) i. m. 98.; KdB (2018) i. m. 8.; PP (2021) i. m. 3.

$87 \mathrm{KdB}(2013)$ i. m. 21.

88 A Lisszaboni szerződés 42. cikk (7) pontja elöírja, hogy az uniós országok valamelyikének a területe elleni fegyveres támadás esetén a többi uniós ország - az Egyesült Nemzetek Alapokmányának 51. cikkével összhangban - köteles minden rendelkezésére álló segítséget és támogatást megadni ennek az országnak. Eur-Lex: Kölcsönös védelmi záradék. [online], 2021. Forrás: eur-lex.europa.eu [2021. 03. 22.]

89 VPR (2011) i. m. 23.; KdB (2013) i. m. 10.; WB (2016) i. m. 91-92.; KdB (2018) i. m. 19.

$90 \quad$ VPR (2011) i. m. 29.; KdB (2013) i. m. 13.

91 BW (2016) i. m. 62.

92 VPR (2011) i. m. 23.; KdB (2013) i. m. 16.; WB (2016) i. m. 92.; KdB (2018) i. m. 26.; PP (2021) i. m. 3.

93 VPR (2011) i. m. 23.; KdB (2013) i. m. 17.; WB (2016) i. m. 92.; KdB (2018) i. m. 19.

94 VPR (2011) i. m. 23.; KdB (2013) i. m. 17.; WB (2016) i. m. 92-93.; KdB (2018) i. m. 28-29.

95 WB (2016) i. m. 93.; KdB (2018) i. m. 29-30., PP (2021) i. m. 3. 


\section{Összegzés és következtetések}

Tanulmányunkban arra a kérdésre kerestünk választ, hogy Németország stratégiai környezetének változásai és az azokra adott válaszok a 2010-es években hogyan jelentek meg a német stratégiai dokumentumokban, és azok milyen stratégiai jövőképet vázoltak. $\mathrm{Az}$ eredményeket azok könnyebb szemléltetése érdekében az 1. táblázatban összesítettük, amelyben átfogó jellegüknél fogva csak a négy stratégiai dokumentumot - a 2011-es Védelempolitikai Irányelveket, a 2016-os Fehér könyvet, valamint a 2013-as és 2018-as Bundeswehr Koncepciót - jelenítjük meg. Mindezek alapján több megfigyelést is megfogalmazhatunk.

A 2010-es években az érzékelt és elöre jelzett fenyegetések földrajzi fókuszát és jellegét vizsgálva kijelenthetjük, hogy mindegyik dokumentum globális és átfogó szemléletü, rámutatva Németország nagyfokú függőségére a nemzetközi eseményektől, különösen kereskedelmi és gazdasági téren. E világkép alapján az ezredfordulót követően a német kül- és biztonságpolitika is egyre inkább nemzetközi kitekintésűvé vált, majd a 2010-es években a müncheni konszenzus nyomán politikai célkitűzésként elköteleződött a nagyobb nemzetközi szerepvállalás mellett. Az erősebb nemzetközi elköteleződést mutatja az is, hogy a 2006-os Fehér könyvvel ellentétben a VPR és a KdB '13 nem számolt hagyományos katonai, területi fenyegetéssel, és egészen 2014-ig a legvalószínűbb feladatnak a nemzetközi válságkezelést tekintették. Ehhez képest a biztonsági környezet változásaira reflektálva a 2016-os Fehér könyv (és az ezen alapuló KdB '18) már újra a területvédelem megnövekedett jelentőségével számol, és többek között Oroszországot nevesíti a kihívások, fenyegetések felsorolásánál. Németország felelős hozzáállását bizonyítja az is, hogy a fenyegetéseknél nemcsak klasszikus (katonai) tényezőket nevez meg, hanem megemlíti például az éghajlatváltozást és az azzal összefüggő kihívások kezelését is.

A vizsgált védelempolitikai iránymutatások mind a nemzetközi együttmüködés fokozását hangsúlyozzák. A NATO mellett az idő előrehaladtával egyre inkább előtérbe kerül az EU KBVP, ezen belül is az Állandó Strukturált Együttmüködés (PESCO) és az ahhoz kapcsolódó kötelezettségvállalások. Mint azt a WB megfogalmazza, Németország hosszú távú célja az Európai Védelmi Unió létrehozása. A NATO-hoz kapcsolódóan a keretnemzetkoncepciót fontos említenünk, amelyet éppen Németország alakított ki, és amely alapján elkötelezett katonai képességeinek a teljes képességspektrumon történő fejlesztésében és a kisebb szövetséges államokkal a védelmi integráció elmélyítésében.

Kivétel nélkül mindegyik iránymutatás a célok lehetöség szerint békés úton történő megvalósítását rögzíti, előtérbe helyezve a diplomáciát, a külpolitikai érdekek érvényesítése pedig elsősorban multilaterális keretek között zajlik, olyan nemzetközi fórumokon, mint az EU, az ENSZ és az EBESZ, de egyéb két- és többoldalú együttműködéseken keresztül is. A WB egyenesen Németország nagyobb politikai-diplomáciai szerepvállalását azonosítja célként az ENSZ-en belül, felelevenítve a német állandó ENSZ BT-tagság ügyét. Habár a dokumentumok a nemzeti célkitűzések békés megvalósítását hangsúlyozzák, azt is tisztázzák, hogy a Bundeswehr az egyik legfontosabb kül- és biztonságpolitikai eszköz, 
és Németország akár fegyveres erővel is részt vehet békefenntartó, de akár békekikényszerítő müveletekben is.

A német politikai vezetés az elmúlt években a NATO európai pillérének erősitésén is dolgozott. Ennek eredménye a dokumentumok elemzésekor is szembetűnő, ha megvizsgáljuk a honvédelem és a nemzetközi műveletek kereteinek meghatározását a különböző iránymutatásokban. Fontos fejlemény, hogy a korábbiakhoz képest a WB és a KdB '18 a NATO mellé beemeli az EU kollektív védelmi kötelezettségét is, így a közös biztonságés védelempolitika a nemzetközi válságkezelő müveletek mellett területvédelmi dimenziót is kapott.

Bár az évtized első felében 2014-ig a gazdasági motivációjú Bundeswehr-reform még a befelé fordulást, önkorlátozást, a katonai erő háttérbe szorítását foglalta keretbe, a 2014-2015-ös stratégiai sokkok a kormányzati konszenzus szintjén is minőségi változást hoztak. A Krím orosz annexiója, a kelet-ukrajnai háború orosz proxyszervezetekkel, az „Iszlám Állam” térnyerése Szíriában és Irakban, a migrációs és menekülthullám Európa irányában, valamint a szélsőséges iszlamista terrortámadások nyomán az évtized második felét a „müncheni konszenzus” elfogadása jellemezte, amit a stratégiai dokumentumok is alátámasztottak. A kialakuló „lépéskényszert” a brexit és Donald Trump elnöksége tovább erősítették.

A 2021-es „Állásfoglalás a Bundeswehr jövőjéröl” (PP) arra hívta fel a döntéshozók figyelmét, hogy a koronavírus-járvány gazdasági hatásai veszélyeztethetik a meghatározott célok megvalósítását, a nagyhatalmi és a megbízható szövetségesi szerepvállaláshoz szükséges képességek kialakítását. Éppen ezért a 2020-as évtized kiújuló nagyhatalmi konfliktusai, instabil biztonsági környezete és a szomszéd térségek válságai, valamint technológiai modernizációs versenye közepette a német politikai elitnek reális, megfelelően rugalmas és megoldásorientált stratégiai gondolkodásra lesz szüksége. 


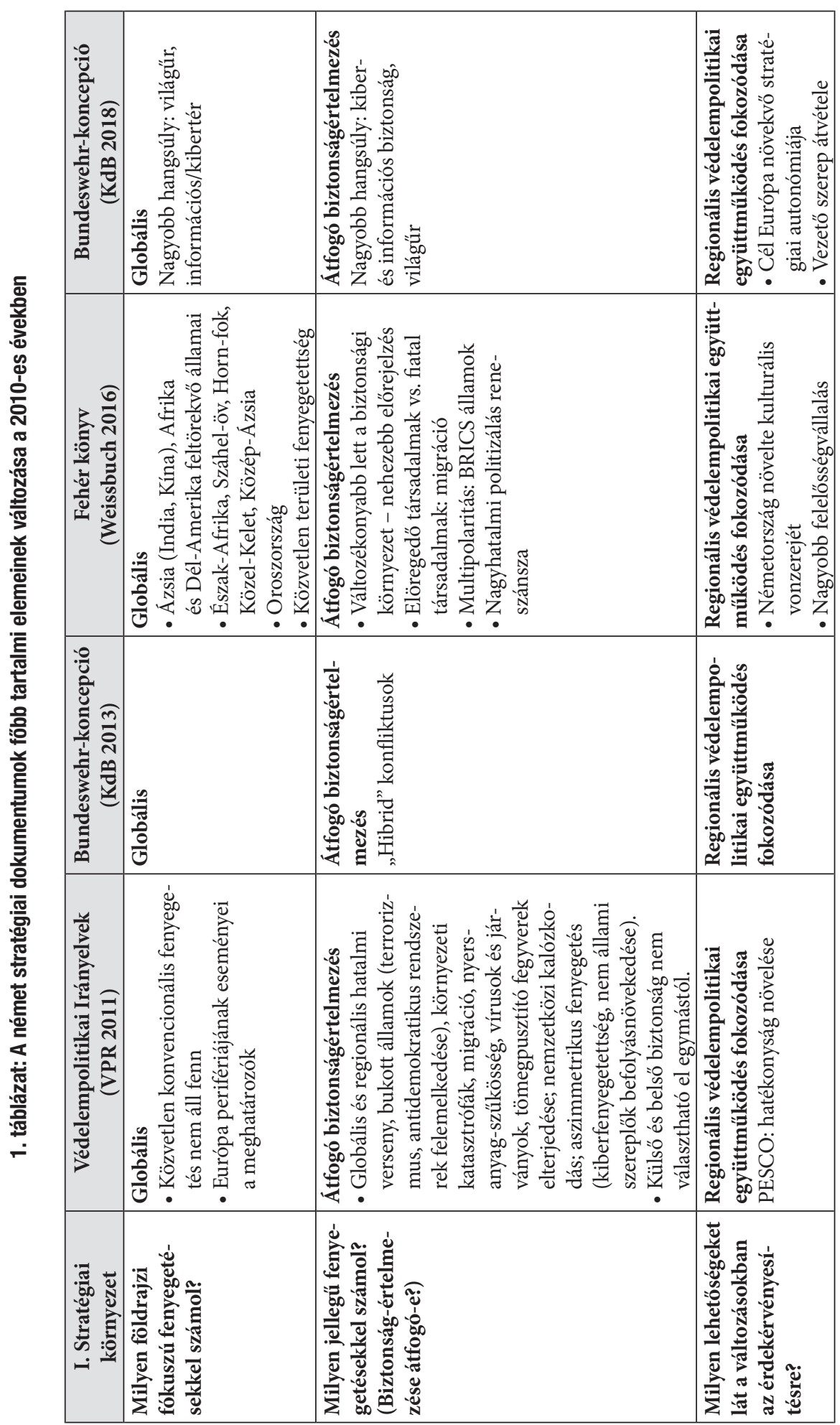




\begin{tabular}{|c|c|c|c|}
\hline 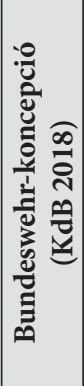 & 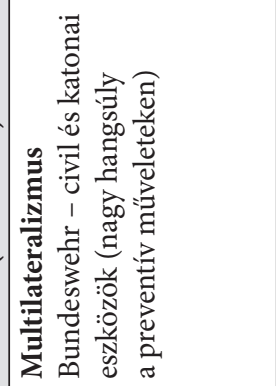 & 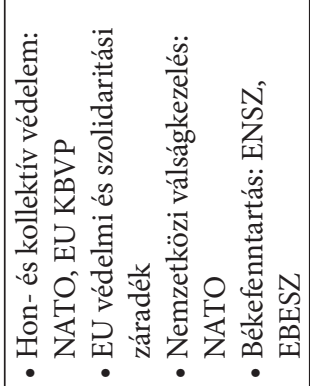 & 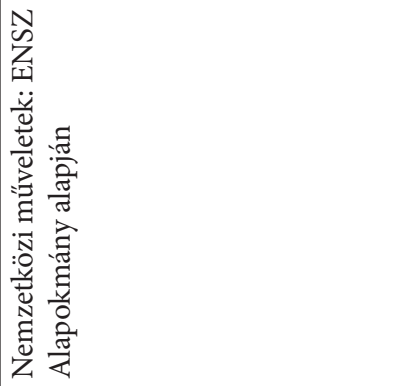 \\
\hline 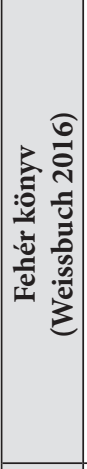 & 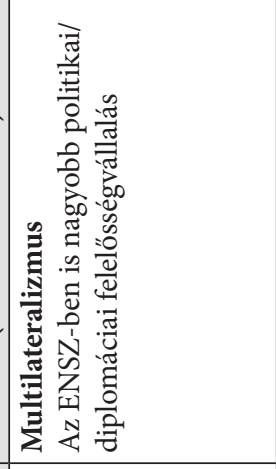 & 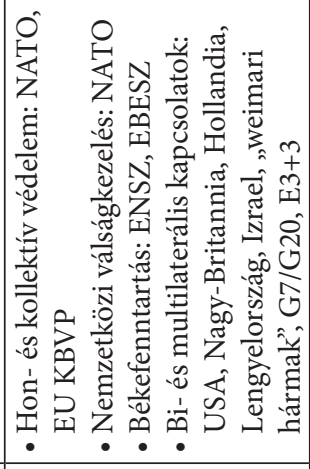 & 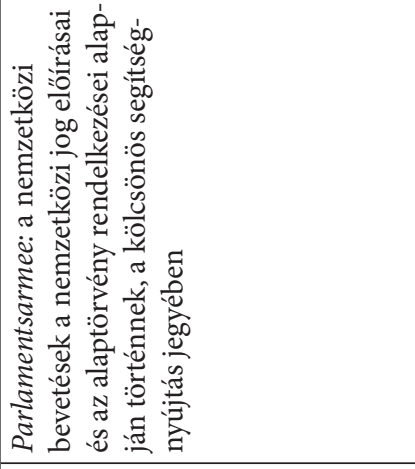 \\
\hline 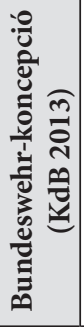 & 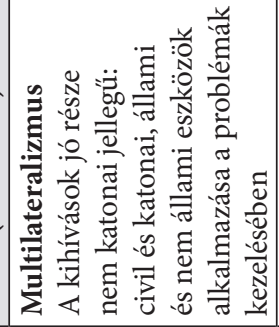 & 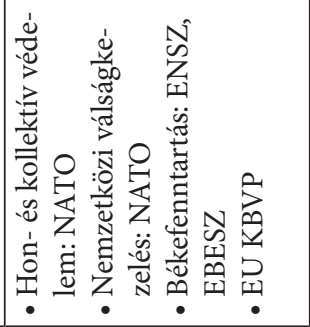 & 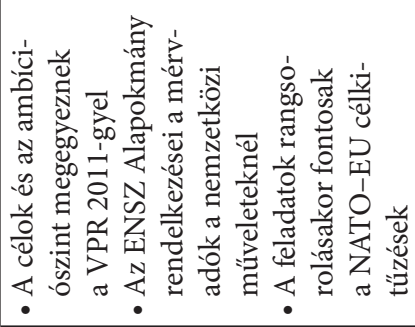 \\
\hline 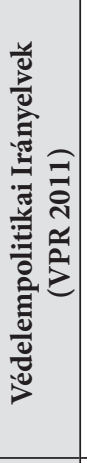 & 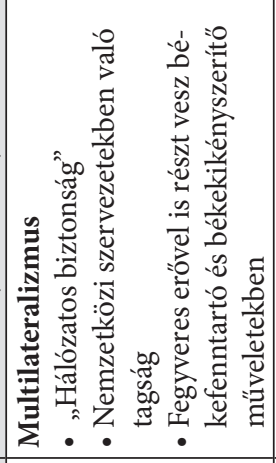 & 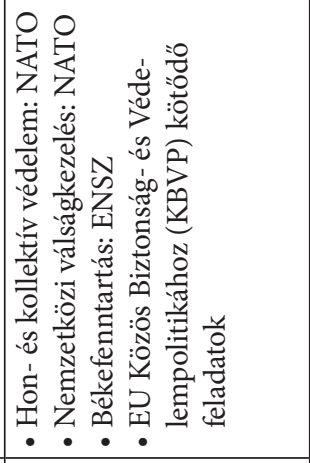 & 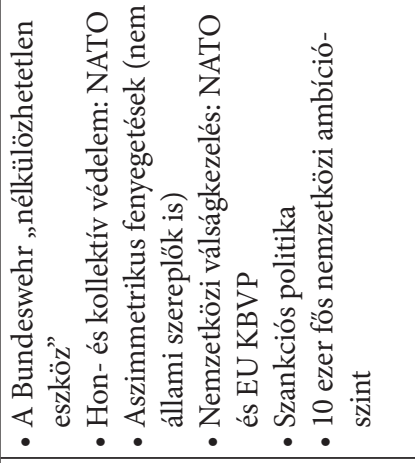 \\
\hline 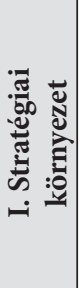 & 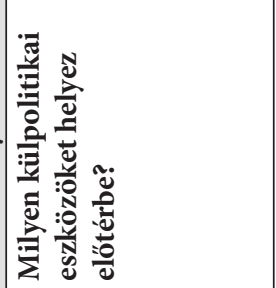 & 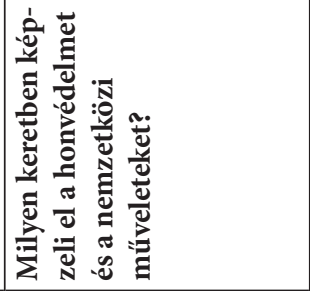 & 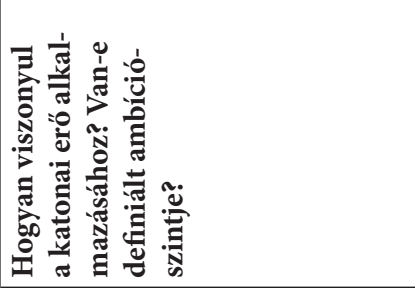 \\
\hline
\end{tabular}




\begin{tabular}{|c|c|c|c|c|}
\hline 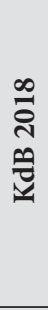 & 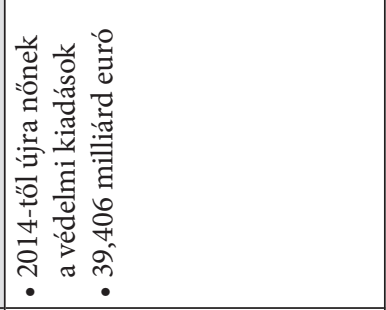 & 1 & 1 & 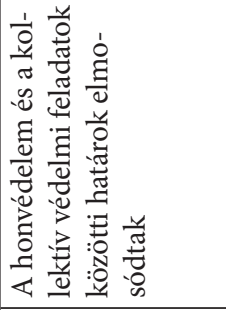 \\
\hline & 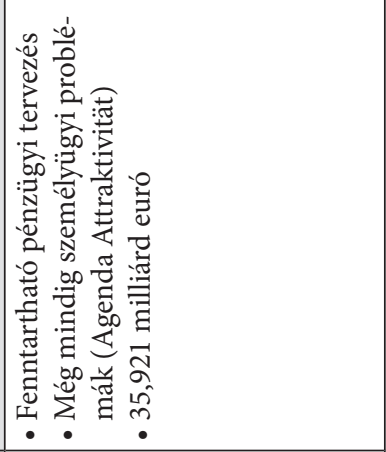 & 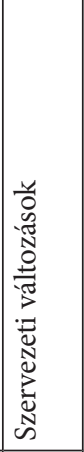 & 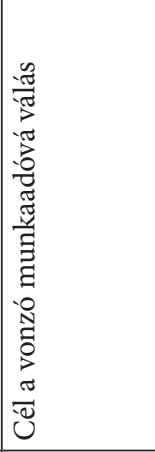 & 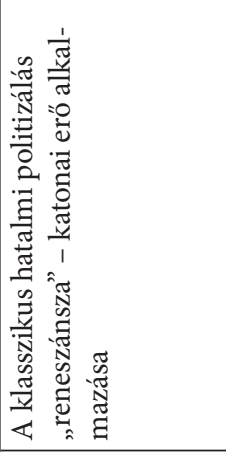 \\
\hline $\begin{array}{l}m \\
\stackrel{n}{\mathcal{N}} \\
\ddot{\theta} \\
\tilde{v}\end{array}$ & 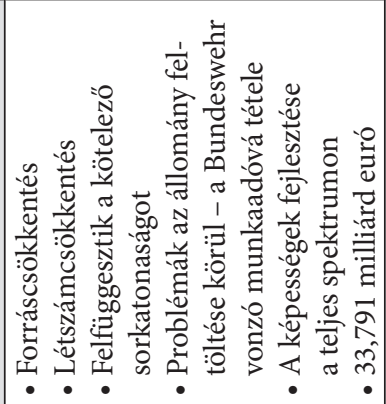 & 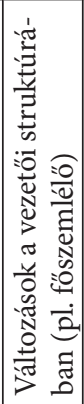 & I & 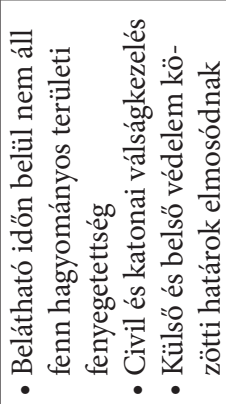 \\
\hline 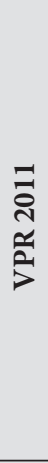 & 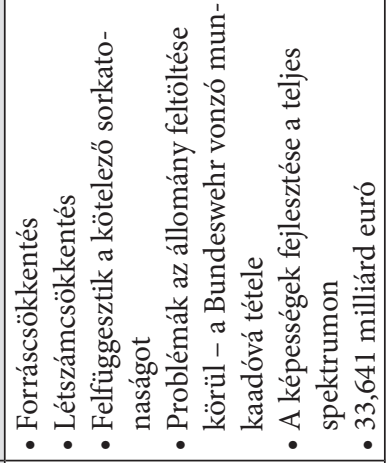 & 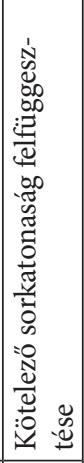 & 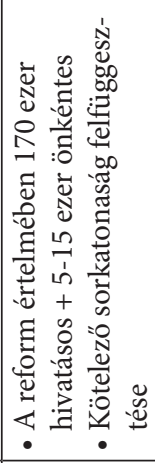 & 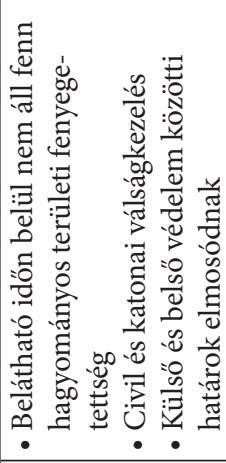 \\
\hline 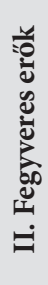 & 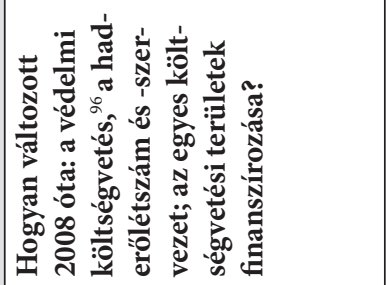 & 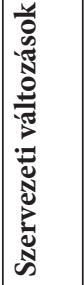 & 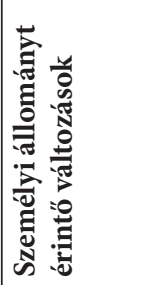 & 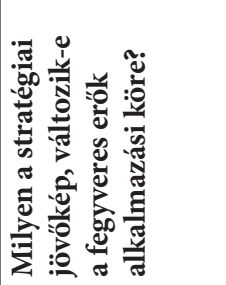 \\
\hline
\end{tabular}

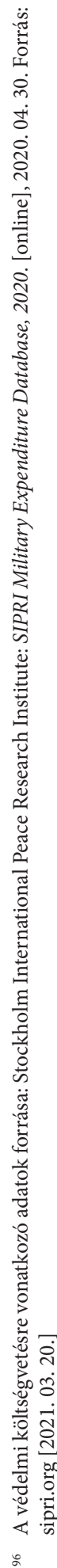




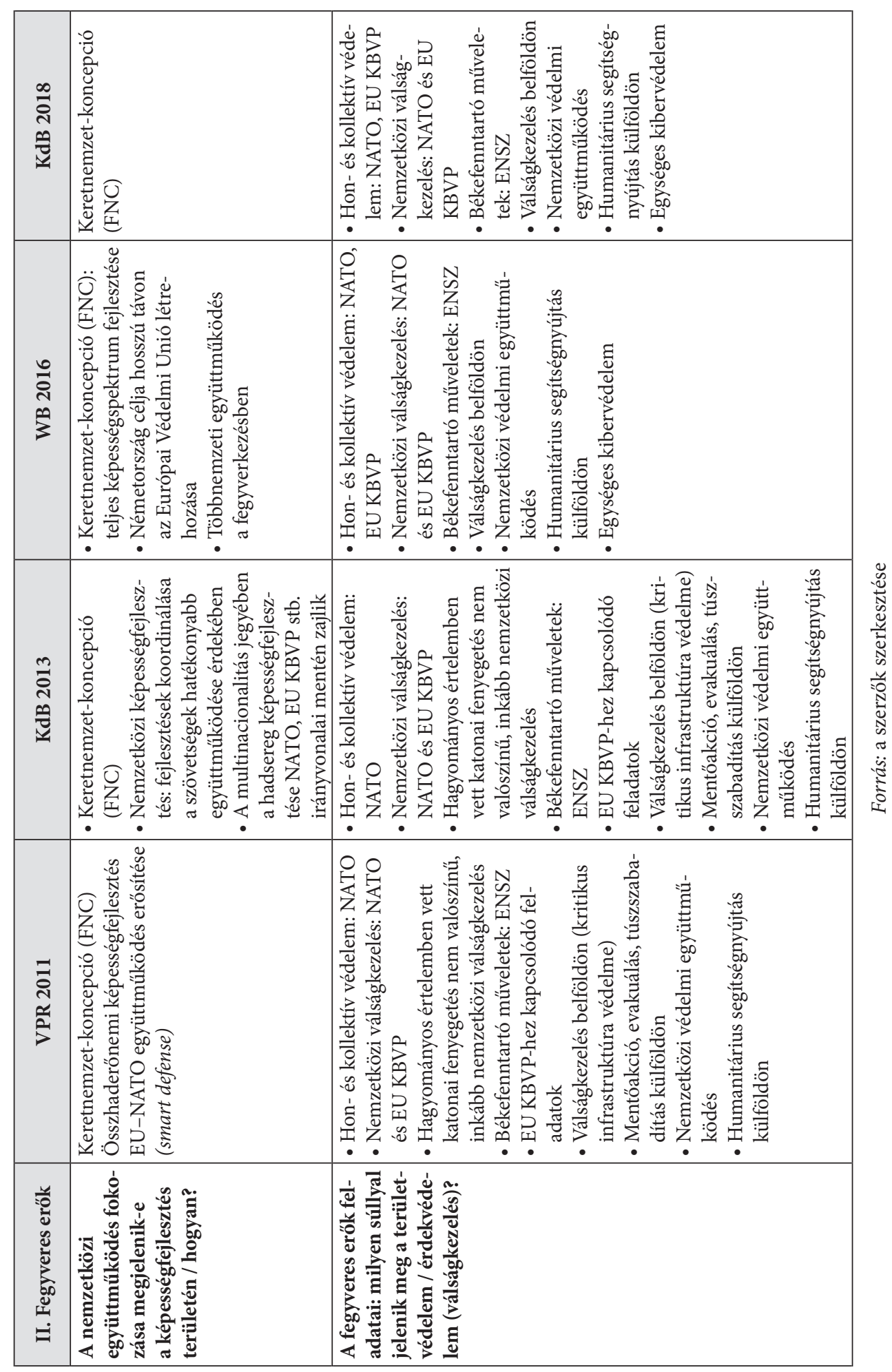




\section{Felhasznált irodalom}

Ablaka Gergely - Csiki Varga Tamás - Csizmazia Gábor et alii: Irak stratégiai érdekek ütközőpontjában. [online], 2020. 07. 31. SVK Elemzések, (2020), 21. Forrás: svkk.uni-nke.hu [2021. 03. 22.]

Biehl, Heiko - Bastian Giegerich - Alexandra Jonas (eds.): Strategic cultures in Europe. Security and defence policies across the continent. Springer, Potsdam, 2013. Online: https://doi.org/10.1007/978-3-658-01168-0

Bundesministerium der Verteidigung: Verteidigungspolitische Richtlinien. [online], 2011. 05. 27. Forrás: bmvg. de [2021. 03. 22.]

Bundesministerium der Verteidigung: Dresdner Erlass. [online], 2012. 03. 21. Forrás: bmvg.de [2021. 03. 22.]

Bundesministerium der Verteidigung: Konzeption der Bundeswehr 2013. [online], 2013. Forrás: bmvg.de [2021. 03. 22.]

Bundesministerium der Verteidigung: Die Agenda Attraktivität. [online], 2014. 06. Forrás: bmvg.de [2021. 03. 22.]

Bundesministerium der Verteidigung: Weißbuch 2016 zur Sicherheitspolitik und zur Zukunft der Bundeswehr. [online], 2016. 07. 13. Forrás: bmvg.de [2021. 03. 22.]

Bundesministerium der Verteidigung: Konzeption der Bundeswehr 2018. [online], 2018. Forrás: bmvg.de [2021. 03. 22.]

Bundesministerium der Verteidigung: Die Konzeption der Bundeswehr - Ausgewählte Grundlinien der Gesamtkonzeption. [online], 2018. 04. Forrás: bmvg.de [2021. 03. 20.]

Bundesministerium der Verteidigung: Positionspapier: Gedanken zur Bundeswehr der Zukunft. [online], 2021. 02. 09. Forrás: bmvg.de [2021. 03. 22.]

Csiki Tamás: A német védelempolitika régi-új alapjai és új felépítménye. Nemzet és Biztonság, 5. (2012), 3. 49-70.

Csiki Tamás: A gazdasági válság hatása a Magyarországgal szövetséges államok védelmi reformjaira és stratégiai tervezésére. Nemzet és Biztonság, 7. (2014), 2. 77-100.

Csiki Tamás: Németország - Európa vezető hatalma, vagy kiszámíthatatlan szövetséges? Nemzet és Biztonság, 6. (2013), 5-6. 63-79.

Csiki Tamás: Az új Nemzeti Katonai Stratégia a nemzetközi tapasztalatok tükrében. Nemzet és Biztonság, 7. (2014), 2. 45-61.

Csiki Tamás: Miért marad továbbra is visszafogott a német védelempolitika? Nemzet és Biztonság, 7. (2014), 5. 97-110.

Csiki Tamás - Tálas Péter: Can we identify a coherent strategic culture in Hungary? In Heiko Biehl - Bastian Giegerich - Alexandra Jonas (eds.): Strategic cultures in Europe. Security and defence policies across the continent. Springer, Potsdam, 2013. 165-180. Online: https://doi.org/10.1007/978-3-658-01168-0

Csiki Tamás - Tálas Péter: Stratégiától stratégiáig. A 2009-es és a 2012-es magyar katonai stratégia összehasonlító elemzése. Nemzet és Biztonság, 7. (2014), 2. 62-76.

Csiki Varga Tamás: A kelet-közép-európai államok védelmi együttmüködési törekvései, 2008-2016. Doktori értekezés. Budapest, NKE HDI, 2018.

Csiki Varga Tamás: Vezetőváltás a német védelmi tárca élén. [online], 2019. 08. 12. SVK Nézőpontok, (2019), 3. Forrás: svkk.uni-nke.hu [2021. 03. 22.]

Csiki Varga Tamás: Ambíció és kockázat: a német külpolitika lehetőségei is korlátjai Líbia kapcsán. [online], 2020. 01. 25. SVK Nézőpontok, (2020), 1. Forrás: svkk.uni-nke.hu [2021. 03. 22.]

Csiki Varga Tamás - Etl Alex: A „müncheni konszenzus” és Németország stratégiai jövőképe. [online], 2019. 09. 19. SVKI Elemzések, (2019), 19. Forrás: svkk.uni-nke.hu [2021. 03. 22.]

Csiki Varga Tamás - Etl Alex: A Németországban állomásozó amerikai katonai jelenlét csökkentéséről. [online], 2020. 06. 22. SVKI Elemzések, (2020), 19. Forrás: svkk.uni-nke.hu [2021. 03. 22.]

Csiki Varga Tamás - Tálas Péter: Erő és diplomácia. Az Egyesült Államok stratégiai érdekei és lehetőségei a Biden-kormányzat időszakában. SVKI Elemzések, (2021), 9. (kézirat).

Etl Alex - Csiki Varga Tamás: A Bundeswehr finanszírozása és készenléte. [online], 2019. 09. 19. SVKI Elemzések, (2019), 19. Forrás: svkk.uni-nke.hu [2021. 03. 22.]

Eur-Lex: Kölcsönös védelmi záradék. [online], 2021. Forrás: eur-lex.europa.eu [2021. 03. 22.]

Hettyey András: A szükséges minimum? Németország szerepvállalása Maliban. [online], 2013. MKI Elemzések, (2013), 5. Forrás: grotius.hu [2021. 03. 22.] 
Hettyey András: A vonakodó szövetséges? - Németország külföldi katonai bevetései a viták és a számok tükrében. Külügyi Szemle, 13. (2014), 1.69-87.

Hettyey András: Különutas kezdeményezések: fordulat a német külpolitikában? Nemzet és Biztonság, 8. (2015), 1. 46-64.

Hettyey András: Németország Közel-Kelet politikája érdekek és értékek útvesztőjében. Hadtudományi Szemle, 10. (2016), 4. 169-197.

Hettyey András: Ki az úr a házban? - A német külpolitikai döntéshozatal struktúrája. Európai Tükör, 20. (2017), 1. 63-77.

Hettyey, András: A Multilateralized civilian power approach: The German foreign policy and Central Eastern Europe. Európai Tükör, 20. (2018), különszám, 71-85.

Kiss J. László: Folytonosság a változásban - külpolitikai stratégia és nemzeti identitás a német fejlődésben. In Kiss J. László (szerk.): Nemzeti identitás és külpolitika az euroatlanti térségben. Budapest, Teleki László Alapítvány, 2005. 51-159.

Molnár Tamás Levente: Németország EU-n kívüli kapcsolatai (1.) Oroszország a szankciós politika tükrében. [online], 2017. KKI Elemzések, (E-2017), 41. Forrás: kki.hu [2021. 03. 22.]

Molnár Tamás Levente: Németország EU-n kívüli külkapcsolatai (2.) - Donald Trump és a felforgatott transzatlanti kapcsolat. [online], 2018. KKI Elemzések, (E-2018), 5. Forrás: kki.hu [2021. 03. 22.]

Molnár Tamás Levente: Németország EU-n kívüli kapcsolatai (3.) Fokozódó óvatosság Kínával szemben. [online], 2018. KKI Elemzések, (E-2018), 35. Forrás: kki.hu [2021. 03. 22.]

Molnár Tamás Levente: Rendszerszintű rivális vagy kulcsfontosságú partner? (1) Németország Kína-politikája. [online], 2020. KKI Elemzések, (E-2020), 58. Forrás: kki.hu [2021. 03. 22.]

Speck Gyula: Németország fejlesztéspolitikája, mint a biztonságpolitika eszköze. [online], 2019. 12. 17. SVKI Elemzések, (2019), 26. Forrás: svkk.uni-nke.hu [2021. 03. 22.] Online: https://doi.org/10.32576/nb.2019.3.3

Speck Gyula: „Germany first” - Az AfD kül- és biztonságpolitikai programja. [online], 2020. 03. 09. SVKI Elemzések, (2020), 6. Forrás: svkk.uni-nke.hu [2021. 03. 22.]

Speck Gyula: A „zöld” külpolitika - A Szövetség '90/Zöldek kül- és biztonságpolitikai programja. [online], 2020. 04. 09. SVKI Elemzések, (2020), 7. Forrás: svkk.uni-nke.hu [2021. 03. 22.]

Stockholm International Peace Research Institute: SIPRI Military Expenditure Database, 2020. [online], 2020. 04. 30. Forrás: sipri.org [2021. 03. 20.]

Szabolcs Laura: Európai stratégiai autonómia - A közös védelem alapjai és korlátjai. Nemzet és Biztonság, (2020), 3. (kézirat). Online: https://doi.org/10.32576/nb.2020.3.3 